DOI: 10.20472/IAC.2020.055.012

DIANA ELENA TOMA (NASTASIA)

Valahia University of Târgoviște, Romania

\title{
ENTREPRENEURIAL INITIATIVE AS A SOLUTION FOR ECONOMIC DEVELOPMENT
}

\begin{abstract}
:
One of the main features of an entrepreneur may be his ability to understand the economic environment as a whole, in terms of challenges, risks and opportunities that may arise in the future. The entrepreneur has an essential role in identifying innovative solutions, being in the position of accessing the opportunities offered by the economic environment, in its dynamics. Recently, progress has been made in studying and understanding the relationship between entrepreneurship and economic growth. However, a comprehensive understanding of the link between creativity, entrepreneurship and economic development is not enough covered the given the extent of knowledge needs in the field.

Therefore, the paper treats entrepreneurship as an essential way for ensuring sustainable economic growth. Also, it pursuits to understand the basics of knowledge creation, the appropriate means of disseminating and communicating innovation and the role of the entrepreneur in this process. The paper is of current interest, given the high interest in entrepreneurship, an approach that can ensure the reduction of economic and social disparities, contributing to long-term economic development.
\end{abstract}

\section{Keywords:}

Entrepreneurship, innovation, management, economy, accounting information, SMEs

JEL Classification: L26, 031, M21 


\section{Introduction}

After decades of progress towards a more globalized world, the value of globalization is now being questioned. Evidences can be found in the officials' public statements against globalization, „Brexit” and the failure of the Trans Pacific Partnership (TPP), all of which are serious distrust of globalization that has been rooted in many of the most advanced economies. The situation is to be found in other western countries that face similar challenges with public opinion that no longer agrees to globalization without reserves.

An important issue is that the benefits of globalization are not shared equally. Many workers perceive globalization as a threat to the job rather than an opportunity to work for a company that sells to foreign markets or buy foreign products for consumers. As such, globalization has been perceived as a burden rather than a profit among many, and politicians have learned to use this view to gain public support.

However, SMEs should be careful not to stop paying attention to globalization. Even without a TPP, there are few tariffs on most of the international transactions. Companies will continue to look for ways to sell to overseas markets and continue to face competition that comes with it. The global economy is interdependent, and this is unlikely to change in the future.

The Organization for Economic Co-operation and Development (OECD) has published a study on the challenges that SMEs face in the global market ${ }^{1}$. The study should strengthen efforts of governments policymakers to remove barriers that hamper the globalization of SMEs, especially "finances and related resources, international contacts and related management knowledge restrictions".

In addition, given that SMEs have a low reputation for public assistance programs, the focus should be addressed on creating and implementing new programs. This usually requires different but repetitive levels of thinking and multi-level reviews and assessments, mainly involving target users and other key stakeholders.

${ }^{1}$ OECD (2009), Top Barriers and Drivers to SME Internationalization, OECD Working Party on SMEs and Entrepreneurship, OECD. 
Through the Action Plan „Entrepreneurship 2020" and the communication „Rethinking education”, the European Commission has emphasized the need to integrate entrepreneurship learning in all sectors of education, including informal learning.

Both documents address to member states in an effort to ensure that all young people obtain a practical experience in the field of entrepreneurship before graduating compulsory education, stressing out the importance of learning through practice in the education and training process.

\section{Background of the study}

Many studies have focused on the article topic, ensuring a relatively good overall knowledge. For example, in Onuoha $^{2}$ opinion, entrepreneurship "is the practice of starting new organizations or revitalizing mature organizations, particularly new businesses generally in response to identified opportunities". For Schumpeter ${ }^{3}$ the entrepreneurs are „individuals who exploit market opportunity through technical and/ or organizational innovation".

Bolton and Thompson ${ }^{4}$ gave another definition to the entrepreneur, considering it as "a person who habitually creates and innovates to build something of recognized value around perceived opportunities" while for Frank H. Knight ${ }^{5}$ and Peter Drucker ${ }^{6}$ the entrepreneurship „is about taking risk".

According to Hisrich ${ }^{7}$, the entrepreneur may be characterized as "someone who demonstrates initiative and creative thinking, that is

2 Onuoha G., Entrepreneurship, (2007), AIST International Journal, pp. 20-32.

${ }^{3}$ Schumpeter J. A., (1965), Economic Theory and Entrepreneurial History. In: Aitken HG (ed) Explorations in enterprise. Harvard University Press, Cambridge, MA.

4 Bolton W.K. and Thompson J.L., (2000), Entrepreneurs: Talent, Temperament, Technique. Butterworth Heinemann, Oxford.

${ }^{5}$ Knight, Frank H., Risk, (1921), Uncertainty, and Profit. Boston, MA: Hart, Schaffner \& Marx; Houghton Mifflin Company.

6 Drucker, P., (1970), Entrepreneurship in Business Enterprise, Journal of Business Policy, Vol: 1.

7 Hisrich, R.D., (2009), Entrepreneurship/ Intrapreneurship, Am Psychol, pp. 209-222. 
able to organize social and economic mechanisms to turn resources and situations to practical account, and accepts risk and failure".

The concept of "entrepreneurship” provides a wealth of insight into thinking about the metabolism and growth of companies, mainly SMEs, and will most likely not lose its appeal in the future.

Economic development in the west was accomplished primarily due to application of science and technology to industrial production. But what did the entrepreneurs do that make them effective as creators of wealth? Schumpeter ${ }^{8}$ provided an explanation, namely that innovation was the source of economic dynamism and entrepreneur was the innovator.

According to Knight, the entrepreneur has the ability to discover favorable circumstances in information asymmetries and market imperfections, while the perspectives of financial gains is what drives the entrepreneur to act. The entrepreneur employs creativity, which involves measurable risks, to make businesses work.

Opportunities are not discovered but created in a process of exploration and innovation, in an environment characterized by uncertainty.

As one of the indicators for investigating whether or not entrepreneurial activities are active, the degree of penetration of entrepreneurs and entrepreneurship into society can be considered.

According to the institutional theory of sociology, if entrepreneurs are socially recognized and the choice of entrepreneurial career and entrepreneurial activities themselves are justified, their existence seems natural. As many studies point out, a network of entrepreneurs may play an important role in the entrepreneurial process.

\footnotetext{
8 Schumpeter, J., (1934), The Theory of Economic Development. Cambridge,
} MA: Harvard University Press. 


\section{Small and Medium Enterprises in Romania}

The analysis regarding the evolution of SMEs active in Romania in the past years refer to low capitalization, high degree of indebtedness, decrease of the short-term investments, low level of the efficiency of the assets, slower collection of the debts and high stocks, above the equilibrium level.

Between 2014 and 2016 the share of economic entities that introduced or implemented new products, processes, methods of organization or marketing methods was of $10.2 \%$, decreasing by 2,6 percentage points compared to the period 2012-2014.

Out of these, $4.8 \%$ were companies that applied only new methods of organization or marketing, while $2.5 \%$ were companies that introduced or implemented only new or significantly improved products and/ or processes.

Out of the total number of enterprises, $2.9 \%$ introduced both new products and/ or processes as well as new or significantly improved organization and/ or marketing methods.

SMEs in Romania concentrate about $15 \%$ of revenues, compared to about $25 \%$ recorded ten years ago, although their share in total economic entities is 95\%, while large companies, although they represent only $5 \%$ of the total active entities, have reached to concentrate $85 \%$ of revenues.

The concentration of incomes among large companies is noticeable in the active business environment in Romania. In total, as of 2017 EOY, in Romania were registered about 700,000 economic entities of which almost 200,000 with no activity, out of the rest of 500,000, somewhere at 28,000 had incomes over one million euro, representing about $6 \%$ of the total active companies.

The analysis regarding the evolution of microenterprises active in Romania shows a modest increase in the profitability of companies with incomes below one million euro, the segment registering constant losses between 2008 and 2014 (about 60 billion lei), while the profits reported in the 2014-2017 period totalized about 7 billion lei. 
The SMEs active in Romania reported a total consolidated profit of only 4 billion lei during 2017 , respectively $2 \%$ of the level of revenues and half compared to the profitability reported by the large companies. The analysis shows that if the revenues and profits are concentrated among large companies, the losses are generalized at the level of the whole business environment.

The overlook on SME environment emphasizes that the phenomenon of polarization in Romanian economic entities is visible from the perspective of the revenues, profits, but also of the liquidity of the companies, the SMEs being more vulnerable in the eventuality of a financial crises in comparison with the situation of the big companies, amplifying the fragility of the middle blanket.

\section{Argument of the paper}

While SME policies primarily focus on economic objectives, there are some systems that place particular emphasis on social objectives; for example, the use of government contracts to support SMEs that are in a competitive disadvantage.

Some SME policies have been influenced by bipolarization, including areas such as healthcare, regulation and taxation. Although support for "freelance" workers is not part of SME policy in Romania, some governmental financing programs for entrepreneurs have been in place, such as „Start-up Nation” or „Start-up Nation Plus”.

The entrepreneurial activities in Romania are not at a high level compared to the countries in the western Europe, thus developing entrepreneurship keeps being an important option for economic growth.

In modern economies, especially developed economies, since the 1990s, various knowledge innovations, including information technology, are constantly taking place. Based on observations of basic data, it can be seen that in Romania, in terms of the number of people and production, the major cities are concentrating most of the growth, confirming that the contribution of SMEs is important both in the non-manufacturing sector and in the manufacturing sector. 
Given this background, a few relevant questions arise: what policies may increase the level of national entrepreneurship and what is the relationship between entrepreneurial activities and economic growth?

\section{Arguments to support the thesis}

All over the world are conducted studied over the impact of entrepreneurial activities on national economy, focused on elucidating the growth process of venture companies, understanding the factors that stimulate entrepreneurship and then quantitatively measure that impact on national economic growth, competitiveness, employment, etc. The ultimate goal is to make policy recommendations that will help revitalize the national economy.

Entrepreneurship is a major driving force for creating new industries and job opportunities, as well as economic growth. In particular, creating an environment in which the young generation, that supports the future society, finds it is easy to start a business is very important for realizing sustainable economic growth, in addition to the implications of expanding the life options of each young person.

Looking at the current state of Romania, with an unpredictable fiscal environment, the number of applicants for entrepreneurship has been declining, while the negative attitude is also conspicuous among the potential entrepreneurs.

In Romania, the reason why entrepreneurs are not prosperous is because the entrepreneurship is weak, there is a large risk of business failure and management resources necessary for entrepreneurship (such as business funds, human resources) are not in hand. It is thought that factors such as lack of know-how and insufficient financial or social returns are being responsible for business failures.

For this reason, it is desirable to take measures in order to support the entrepreneurship with an awareness of solving each of these factors. Specifically, there is a need for measures that can cultivate entrepreneurship, in close cooperation with the educational field, such as meetings with entrepreneurs, entrepreneurship experience sharing and practical oriented education. As for risk reduction and a safety net 
in case of business failure, there must be enhanced the measures such as vocational training and reemployment support.

\section{Entrepreneurship perspectives in Romania}

One of the issues faced by Romanian SMEs is the aging of the population that is progressing rapidly, while a large number of wellprepared youths are considering leaving the country as soon as they have finished their studies, looking for betters work condition and higher wages. As SME owners age, they face the challenge of creating the "successor" of their business. Various methods are discussed, such as selling the business or leaving the business to future generations.

At the same time, the SMEs are currently facing globalization issues. As it will be explained below, this is no longer a problem only for SMEs preparing for the global market. This is because the value of globalization itself has been the subject of discussion lately.

So, how may the Romanian entrepreneurs flourish, other than by being sustained through policy measures, in the context of a globalized economy? Well, the answer may be found in adapting to the so called Fourth Industrial Revolution (also known as „Industry 4.0”).

The Fourth Industrial Revolution is a new type of industrial production term that fully integrates digital technologies such as networking and computerization into all aspects of the production process.

The new digital economy is possible with Industry 4.0 that offers opportunities and challenges for entrepreneurs ${ }^{9}$. The major innovation behind Industry 4.0 lies in the use of small computer systems with IP addresses and wireless communication interfaces embedded in manufacturing machines, materials and end products.

These computers enable machine-to-machine (M2M) communication. Automated M2M networks are used to build smart factories that are flexible, efficient, and reduce the cost of complexity. If there are advantages and challenges for SMEs, the focus should be on adapting

${ }^{9}$ C Schroder, (2015), The Challenges of Industry 4.0 for Small and Medium-sized Enterprises, Friedrich Ebert Foundation. 
to cross-border logistics enhanced by digitization ${ }^{10}$, use of data flows, improve data integration for supply chains and integrate different data systems.

The Internet of Things (IOT) is also an element of Industry 4.0. With loT devices expected to reach 50 billion by 2020 , the growth potential for SMEs is not to be denied. Much of the business potential for start-ups comes from data generated from these loT device environments. Business plans for analyzing loT data are low entry barriers for SMEs. This is especially true when combining cloud computing and big data technologies.

Another element of adaptation to Industry 4.0 is the use of "big data” by SMEs. As part of this, SMEs collect data on their activities and conduct analysis to better understand their customers and markets; they also analyze datasets from external sources, find patterns in these datasets, and take advantage of these patterns.

The main strategy for "big data” development is the use of cloud computing, which reduces costs and allows entrepreneurs to try new strategies with a small initial investment. Another section of Industry 4.0 refers to the potential use of artificial intelligence (AI) by SMEs.

There are already several services that SMEs can use artificial intelligence for, including translation applications, artificial intelligence services, sales support artificial intelligence services, and various small artificial intelligence services.

An alternative funding mechanism for SMEs has emerged as an effective way to fill the capital raising gap, where financing cannot be obtained from commercial banks. Alternative funding mechanisms include asset-backed financing, equity finance, hybrid securities, alternative debt, venture capital and angel investments.

Internet technology has enabled two new types of alternative financing: crowdfunding and trade finance via cryptocurrencies and blockchain.

10 World Economic Forum, (2016), World Economic Forum White Paper: Digital Transformation of Industries. 


\section{Conclusions}

The innovation brought through the new digital economy provides opportunities and challenges for entrepreneurs. There may be needed that certain policy framework to be adopted in order to remove barriers for digital entrepreneurs and give them opportunities.

The biggest common challenge for entrepreneurs to be successful is to develop an appropriate digital business strategy, conduct cost-benefit analysis and address the lack of data security and certain technical standards.

A particular opportunity for entrepreneurs is the cross-border flow that has been enhanced through digitalization. These platforms connect individual sellers and potential individual buyers around the world. The digital economy allows small entrepreneurs to easily connect with third-parties in order to meet logistics needs such as customs procedures, international trade and payments upon import.

In conclusion, entrepreneurship is mostly about risks, innovation and creative thinking, the entrepreneur being the one who creates and innovates something by taking advantage of opportunities and accepting risks and risk of failure.

\section{Acknowledgement}

This paper was co-financed from the Human Capital Operational Program 2014-2020, project number POCU / 380/6/13/125245 no. 36482 / 23.05.2019 "Excellence in interdisciplinary PhD and post-PhD research, career alternatives through entrepreneurial initiative (EXCIA)", coordinator The Bucharest University of Economic Studies".

\section{References}

OECD (2009), Top Barriers and Drivers to SME Internationalization, OECD Working Party on SMEs and Entrepreneurship, OECD.

Onuoha G., Entrepreneurship, (2007), AIST International Journal, pp. 20-32. 
Schumpeter J. A., (1965), Economic Theory and Entrepreneurial History. In: Aitken HG (ed) Explorations in enterprise. Harvard University Press, Cambridge, MA.

Bolton W.K. and Thompson J.L., (2000), Entrepreneurs: Talent, Temperament, Technique. Butterworth Heinemann, Oxford.

Knight, Frank H., Risk, (1921), Uncertainty, and Profit. Boston, MA: Hart, Schaffner \& Marx; Houghton Mifflin Company.

Drucker, P., (1970), Entrepreneurship in Business Enterprise, Journal of Business Policy, Vol: 1.

Hisrich, R.D., (2009), Entrepreneurship/ Intrapreneurship, Am Psychol, pp. 209-222.

Schumpeter, J., (1934), The Theory of Economic Development. Cambridge, MA: Harvard University Press.

C Schroder, (2015), The Challenges of Industry 4.0 for Small and Mediumsized Enterprises, Friedrich Ebert Foundation.

World Economic Forum, (2016), World Economic Forum White Paper: Digital Transformation of Industries. 